\title{
Ritual Request to the Green One for Rain Suspension - Serial No. 88302753
}

\author{
Brian Durán-Fuentes, Alicia Rita Rueda-Acedo
}

\section{Ritual Request to the \\ Green One for Rain Suspension - Serial No. 88302753}

By powers granted in inks red and black upon the age of the fifth sun, By explicit permission of the Lord and Lady of Our Flesh, By will of the cosmic power which audits all processes without mercy, I, Rabbit, I, Twelve, I, Movement, I, Priest of Temple 4, Unit 7 ,

Hereby request on behalf of his humble servant to my right hand, For the flight of herons and the sleep of frogs to formally summon You, You, the inveterate resident of caves, You for whom the serpents choreograph The most jovial of dances, and procure an adequate etiquette when swallowing children,

In order to request that on the coming date of Year: Five, House - Day: Two, Dog You omit to tilt your vessel of rains upon the realm of the living, As on that day, your servant in question, who toils upon the land as an Uber driver Is to give his daughter's hand in marriage and celebrate the aforementioned event

As tribute his servant offers the skin of the jaguar, shells found at the belly of the sea, And 12 large boxes of SNICKERS (nougat bars topped with caramel, peanuts and chocolate) Bearing in mind that this request and all related tributes and forms submitted Do not in any way guarantee the fulfillment of this human wish before divine will.

- Recited and validated in blood by the issuing priest on: 


\section{Oración a Nuestro Señor Verde para que nos conceda un ritual que suspenda la lluvia - Número de serie 88302753}

Por el poder que se ma ha conferido en tinta roja y negra según la llegada del quinto sol, Por medio del consentimiento explícito de Nuestro Señor y Nuestra Señora de la Trémula Carne y Por voluntad del poder cósmico que auditoría todos los procesos judiciales sin merced alguna, Yo, Conejo, yo, Duodécimo, yo, Movimiento, yo, Sacerdote del Cuarto Templo, Unidad 7

Por medio de la presente solicito a nombre del humilde siervo a mi diestra que sea usted convocado por el vuelo de la divina garza y por el sueño de la ranas. Sí, usted, el inveterado habitante de las cavernas por quien las serpientes ejecutan las más jovial de las danzas mientras engullen niños procurando guardar reglas básicas de etiqueta

Y para solicitarlo en fecha venidera del año, cinco, casa, día, dos, perro Imploro que no derrame sus cántaros de lluvia sobre el reino de los vivos Ya que en ese día, su siervo en cuestión, el que se desloma sobre la tierra como conductor de Uber, va a conceder la mano de su hija en matrimonio y a celebrar dicho enlace

Como tributo, su siervo ofrece la piel del jaguar, conchas halladas en el vientre del mar y 12 cajas grandes de SNICKERS (barritas de turrón cubiertas de caramelo, avellanas y chocolate) teniendo en cuenta que esta petición, todos los tributos relacionados y los formularios enviados no garantizan el cumplimento de tal deseo humano ante la voluntad divina.

—Recitado y validado con sangre por el sacerdote que expide la presente en

$$
\begin{array}{r}
\text { el año cuatro del p } \\
\text { edernal, a día } \\
\text { diez del agua, } \\
\text { del mes } \\
\text { de la } \\
\text { cascada. }
\end{array}
$$

Traducción: Alicia Rita Rueda-Acedo 